\title{
Management Education: A Key Element For The Development Of Private Enterprises In Latin America. The Case Of Ecuador
}

\author{
John D. Theodore, Warner University, USA
}

\begin{abstract}
The purpose of this article was to determine the availability of management education in Ecuador and the usage of it by the management of private enterprises in the country. Management's importance in the economy of a nation is paramount because it is responsible for the success or failure of businesses, which are the foundation stones of the free enterprise system. In turn, one of the most essential prerequisites to effective management is management education because it increases the knowledge, skills, and productivity of managers. The benefits of a better management education are improved ability to identify viable business opportunities; less resources waste on ill-conceived ventures; enhanced competitive edge internationally; improved job satisfaction and retention of personnel; and improved effectiveness in the turbulent external environment. It was concluded that in the educational sector Ecuadorian private enterprises are not currently in a position to contribute toward economic development because their managers do not have the necessary and commensurate managerial education
\end{abstract}

Keywords: Management education, organizational development, European heritage of Latin America, Alliance for Progress, globalization, CLADEA (Latin American Council of Post Graduate Business Schools)

\section{INTRODUCTION}

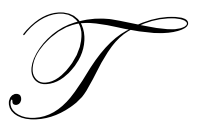

he current Ecuadorian President, Rafael Correa, is favoring a socialist and macroeconomic model of economic development, whereas the private sector is supporting a microeconomic approach. Correa's economic plan of 2007-2010 proposes to achieve economic revitalization through social justice and freedom under the auspices of the government (Luna Osorio, 2007). Ecuador's private sector favors a free-market approach whose infrastructure is predicated on the productivity, performance, and competitiveness of the country's private enterprises. Proponents of an economy based on the free market system claim this classic form of economics will be conducive to the development of all economic factors, especially the human one, because it provides and sustains freedom (Lucio-Paredes, 2008).

The author of this work is producing a series of articles - the current article is the second in the seriesabout the current and future status of the Ecuadorian economy (Theodore, 2009). The previous article identified and evaluated the prerequisites needed in Ecuador's private enterprises that are conducive to economic development to ascertain if a free- market microeconomic approach to economic development is feasible at the present time. In order for private enterprises to reach a level of effective and efficient performance, they need to meet certain important prerequisites. According to the writer's Holistic Management model (Theodore, 2003), such prerequisites start with an ample organizational size, a situation that allows the formation of a well constructed and viable organizational structure with three hierarchal levels, and sufficient departmentalization. All of the above conditions permit the formation, sustenance, and development of the chain and unity of command, span of control, and delegation which, when integrated with the organizational structure, organizational levels, and departmentalization, form the infrastructure for organizational development. 
Organizational development is a planned change effort which involves all the parts of the organization (Schein 1988). It is initiated and managed from the top hierarchy of the system and it is designed to increase organizational effectiveness. The ultimate goal of organization development is to make the organization more open and more adaptive through increases in capability and potential so it can continue to make such planned change efforts on an action orientation basis (Theodore, 2002). It was concluded that Ecuadorian private enterprises are not currently in a position to contribute toward economic development because the Ecuadorian economy is composed of a very large number of private organizations of small size. Small and medium sized enterprises constitute $97 \%$ of all enterprises in the country (Vasquez \& Santos, 2008). This factor is a tremendous impediment toward the creation of a critical mass of appropriately sized organizations - a minimum of 30 employees and managers-- that can utilize the above-mentioned organizational structures. Ecuador's private sector is characterized by enterprises that typically employ small numbers of family members who function both as managers and employees. The average number of persons employed is three (Hurtado, 2007). The small size and proliferation of family owned and managed enterprises (and consequently the traditional hierarchal, rigid structure) have impeded their economic development and modernization of management techniques. Two immediate actions have been offered to ownership and management of such enterprises: (1) conduct mergers that will precipitate larger organizational size (Arosemena 2007) and (2) provide advanced management education for private enterprise managers and entrepreneurs (owners) managers - both to be identified as managers in this article - in order for them to be qualified and ready to implement the advanced managerial and organizational practices needed by the newly formed and emerged enterprises (Theodore, 1999).

The purpose of the current article is to determine the availability of management education in Ecuador and the usage of it by the management of private enterprises in the country. Management's importance in the economy of a nation is paramount because it is responsible for the success or failure of businesses, which are the foundation stones of the free enterprise system. In turn, one of the most essential prerequisites to effective management is management education because it increases the knowledge, skills, and productivity of managers.

\section{THE EUROPEAN HERITAGE OF LATIN AMERICA}

In Latin America, management education began playing an important role in fostering the region's economic, commercial and industrial development since the late 1980s. However, this was not the case in the past. In Latin America, economic prosperity was considered a condition that militated against the ethical-spiritual aspects of a person. One strand of thought maintained that the accumulation of profit was anathema to religious doctrine. Management, one of the factors of production, and one of the preponderant precipitants of economic and industrial growth, was especially hostile to that religious ideology. For this reason, management education was neglected. This was not only true in Spanish America, but also in Luso-America, where the Church theology was traditionally more liberal. Such an inclination had its roots in the ancient Greek and Latin philosophy regarding commerce and industry. Classical Greece, from which the Latins inherited extensively, was under the social, political, and economic influence of Plato and Aristotle. Both men advocated an agrarian society in which agriculture was considered the noblest profession of all, followed by the military. Commerce and industry were regarded as necessary evils, and the occupation of the businessman and manager was considered of lesser importance

Aristotle followed Plato and, in many ways, overshadowed Plato's position regarding the place of commerce and industry in the classic Greek world's cosmos. Aristotle concurred with Plato in ideas regarding trade and industry and considered them to be professions of lesser esteem. This philosophy was accepted by the ancient Latins, and left its negative impact on their view of industry and trade (Theodore, 1971). This classic Greek philosophy, however, might have been gradually effaced had not the Catholic Church assumed a dominant role in determining what was right for society in all phases. Among other concepts, the Church and many components of civil society willingly embraced Aristotle's philosophy vis-à-vis trade and commerce, and adopted most, if not all, of the Aristotelian ideology. Although the Church was spit administratively in the $11^{\text {th }}$ century, Aristotelian ideas were profoundly engrained in both the Roman and Greek Churches and societies. Specifically, the ultimate goal of the Church was the salvation of mankind; accordingly, every effort was made to direct the attention of the congregation to this end. Anything that might impede religious guidance toward salvation was considered evil because it detracted from man's full dedication to religious salvation. 
The social status of management, a factor of production and an important precipitant of economic and industrial development, was kept low and was considered inferior to other professions, such as the fine arts, law, or medicine. The Church, which had control over the entire educational system in Latin America, was able to perpetuate this condition by neglecting, if not suppressing, management education. It should be carefully noted, however, that while the Church ignored certain curricula, it also educated Latin Americans and fostered most of the sense of scholarship in the New World. It contributed to the establishment of excellent universities, such as those of Santo Tomas de Aguino (1538), Santiago de la Paz (1540), Mexico City (1551), and Lima (1551). By 1624 there were twenty-six universities in Latin America. Nonetheless, the Church wielded great influence, not only in the spiritual sector, but also in political, societal, and the intellectual pursuits. Hence, the traditional hostile disposition of the Church and society towards curricula in management education went unchanged until recently.

\section{THE EVOLUTIONARY PROCESS OF MANAGEMENT EDUCATION}

Due to lack of formal training, as late as 1960, only a very small number of enterprises had managers with management education. Even business leaders had scoffed at management education and at research in management and business. Researchers in these areas were thought to be eccentric individuals alienated from the real world. Most managers had law and engineering degrees. Law schools incorporated basic curricula in economics in order to provide rudimentary education for those who wanted to be managers.

Several countries in Latin America began to establish business school programs in the 1960's. Several significant barriers retarded the growth of business education, such as limited private investment in academic and practical management education and in many situations the national government was also very reluctant to invest funds in the business curricula. Latin Americans who had studied management in North America or Europe were either underemployed or unable to find a suitable position at home. As a result, many of them returned to the nations where they had studied in search of productive employment (Schwalb, Grosse, \& Simpson, 1998). However, the field of management education was not completely obliterated in Latin America.

Although American and British business enterprises entered the Latin American market at the turn of 1900s, especially in the Southern Cone area, their influence in changing management practices and introducing management education was limited. However, there were several forces in the 1960's that changed the traditional attitude of the Church and society toward management education: (1) the desire of national governments to develop their countries economically; (2) the economic challenge of Fidel Castro in Cuba as an instrument of the Soviet Union; and (3) the Alliance for Progress.

The pre-World War II international economic disaster of the Great Depression affected the economies of Latin America severely because they were the mere suppliers of raw materials to industrialized nations. To remedy the situation, Latin American national governments decided to participate actively in the economic affairs of their national states. Of primary significance were development and the elevation of the standard of living for the masses. However, economic growth and development was to be achieved through local patterns rather than North American or European ones.

In the 1960's, the emergence of Fidel Castro and the presence of the Soviet Union and its Marxist/Leninist philosophies regarding economic management of a national economy provided not only a socio-economic alternative to the status quo but also a challenge to the process of economic development and the attainment of a mass market. An important appeal of the Soviet Union in Latin America was the temporary success of the Soviet economic development at that time. Many Latin American intellectuals and political leaders were profoundly concerned with discovering the magic of economic growth and the appeal of the Communist economic model was widespread. The new Cuban values applied in Latin America were abundant, and Fidel Castro promised that the decade of plenty was beginning.

The most direct influence, however, was the implementation of the Alliance for Progress in 1961, an instrument for social and economic development. The economic aim of the Alliance for Progress was to accelerate economic development. Goals included fair wages and satisfactory working conditions, fiscal and monetary reforms, 
the stimulation of private enterprise in order to encourage economic development, and the economic integration of Latin America.

To attain the desired economic development, Latin America had to utilize adequately the factors of production. For this reason, the establishment and development of good management education became necessary. As a result, the Church and society changed their attitudes toward management education in order to stimulate economic prosperity, and thus improve social conditions. Clearly, the Church had much to lose in a society under the leadership of the dictatorship of the proletariat. This transformation of ideology was officially supported by the Vatican. In his Apostolic Letter commemorating the $80^{\text {th }}$ anniversary of the Rerum Novarum Encyclical, Pope Paul VI clearly stated that in order to avoid misery and parasitism in the human race in the future, the Church must support the government's policies towards economic investments, the organization of production, the increase of commerce and industry, and in general, towards every aspect of improving the economy (Theodore, 1971).

Some of the most impressive improvements in management education mainly in the advanced nations of the region (Argentina, Uruguay, Chile, Brazil, and Mexico) were the increase of academic curricula in business and management, the creation of institutions responsible for theoretical and practical instruction in managerial education, and the closer cooperation between Latin American and North American universities and institutions of higher learning in the 1970's. Many Latin American nations created curricula in management education in their established institutions of higher learning. Institutions offering practical instruction and training in management education were also established. Two good examples were A Universidade Do Trabalho, in Brazil, whose education to in-service managers became very important for the nation, and El Instituto Centroamericano de Administración de Empresas, in Nicaragua, dedicated to undergraduate and graduate specializations in management in Central America.

Additionally, a large number of U.S., Canadian, and European institutions of higher learning offering programs in management education began to cooperate closely with Latin American universities and business schools mostly in the advanced nations of the region. This cooperation continued to increase, according to an agreement reached in a conference at Mexico City in 1974, and as a result more Latin Americans showed sincere interest in management education. Consequently, the percentage of students matriculating in such curricula increased.

Furthermore, Latin American nations appeared to develop an emphasis on the preparation for management positions. In addition, the social status of managers was improving rapidly and the remuneration of managers was increasing.

Comparative studies in the early 1970's, however, presented the need for further improvements in management education. Such studies indicated that the majority of Latin American managers did not have adequate managerial education. This situation became a great concern in Latin America in the early 1970's, a period during which the region was exposed to constant pressure for accelerating changes, globalization, technological changes, and shifts in the labor force. Such dynamics became catalysts of change for management education. Those involved in management education took into account that shifts in the overall educational arena. The challenge for management education has been to help Latin American students learn to manage changes ethically, effectively, and efficiently, whether the issues involve international boundaries, human resources, financial considerations, political constraints, asset allocations, work ethics, process and productivity, total quality management, or a combination of any of those factors.

In the late 1980's and early 1990's, the driving forces of globalization, constant change, and evolving international standards of competitiveness required Latin American organizations to re-examine both the structural and operational aspects of how to create and sustain a competitive advantage. A key issue was to employ individuals who demonstrate the attitudes and skills necessary for success in this area. For this reason, mainly in advanced nations in the region, university business programs began to prepare students to meet the needs of industry by providing programs offered by other universities within and outside the area. This was accomplished through adhering to generally accepted curriculum standards and outcomes expectations for graduates of such programs. 
The benefits of a better management education were: 1) improved ability to identify viable business opportunities; 2) less resources waste on ill-conceived ventures; 3 ) enhanced competitive edge internationally; 4) improved job satisfaction and retention of personnel, and 5) improved effectiveness in the turbulent external environment.

By the end of the 1980's, enrollment in management education subjects increased in most Latin American nations, beginning with undergraduate curricula and subsequently followed by graduate ones. From the end of the 1980 's to 1998, an explosion of graduate managerial education took place throughout the region. Existing institutions were adding and increasing curricula in management education and new institutions were established for the same purpose. Among the many universities that offer management education in the region are the University of Bucaramanga in Colombia, ESPOL in Ecuador, and the University of the Pacific in Peru. A large number of these institutions are members of the CLADEA (Latin American Council of Post Graduate Business Schools), which was founded in 1967.

Due to the growth of management education curricula in the 1980's and 1990's, management is now considered to be a profession in the advanced states of the region. In addition to the increased demand for professional managers, occupational profiles and job descriptions include knowledge and skills which are characteristic to this profession. Legal enactments formalize the practice of management in most Latin American countries.

\section{THE CASE OF ECUADOR}

At the present time in Ecuador there are 66 universities and polytechnic schools, 26 of which are state institutions. There is also a small number of foreign universities. The percentage of students in education, humanities, social sciences, and administration is $61 \%$. In healthcare, physical science, mathematics, and agriculture the percentage is 22\%; and in engineering and technologies 15\%, respectively (Hurtado, 2007). In comparison to the total population of Ecuador, university enrollment is relatively low. Recent statistics indicate that less than 18\% of those who are 24 years old and older are formally attending universities or taking classes at universities (Ospina Peralta, 2007). Table 1 depicts the Ecuadorian universities that have business administration curricula.

As is the case in all Latin America, most university professors in Ecuador have an undergraduate degree only. This is very evident in the area of business administration. Fewer than four percent of them have a doctoral degree which, most cases, is not related to business curricula (Haar \& Price, 2008). Curricula dedicated to educating managers are very limited. There is, however, an initiative to expand such programs but cultural resistance is impeding the process. Attempts are made to increase the esteem of managers in which the Ecuadorian society holds them (Tiffin, 2004). Lamentably, government support in increasing management education remains limited (Rigail, 2006). Furthermore, managers are also responsible for resisting such education due to cultural and economic reasons (Arosemena, 2007). Most of the managers who have university education have degrees in law, engineering, and finance; not in management. Studies in management require a change in the mentality of the Ecuadorian managers (Rigail, 2008).

Ecuadorians who have studied in North America and Europe and who are teaching business administration curricula in higher education and consulting in the same area are pressing for changes. The study of management education needs to become a life-long study in order to assist the management of private enterprise to attain the required mission, goals, and objectives (Crespo Merchan, 2008). Managers must change their culture and become visionaries and experts in all facets of management. Such capabilities are characteristics of advanced organizations conducive to creating and developing competitive markets. Universities need to offer commensurate management education in order to assist in this developmental process (Rigail, 2008). Each manager needs to continuously be responsible for his/her managerial education and for the commensurate education of the subordinates in the organization. 
Table 1: Ecuadorian Universities with Business Administration Curricula, January 2009

\begin{tabular}{|c|c|c|c|}
\hline University & Undergraduate & Graduate & PHD \\
\hline $\begin{array}{l}\text { The Universidad Técnica Particular } \\
\text { de Loja (Loja) }\end{array}$ & $\begin{array}{l}\text { Bachelor in Business } \\
\text { Administration }\end{array}$ & $\begin{array}{l}\text { Post graduate Certificate in } \\
\text { Administrative Management Skills }\end{array}$ & \\
\hline $\begin{array}{l}\text { Universidad Espiritu Santo } \\
\text { (Samborondón) }\end{array}$ & $\begin{array}{l}\text { Bachelor in International } \\
\text { Business }\end{array}$ & $\begin{array}{l}\text { Master in Business Administration } \\
\text { (MBA) }\end{array}$ & \\
\hline $\begin{array}{l}\text { Escuela Superior Politecnica Del } \\
\text { Litoral (Guayaquil) }\end{array}$ & $\begin{array}{l}\text { Bachelor in Business } \\
\text { Administration }\end{array}$ & $\begin{array}{l}\text { Master in Business Administration } \\
\text { (MBA) }\end{array}$ & \\
\hline $\begin{array}{l}\text { Universidad San Francisco De } \\
\text { Quito (Quito) }\end{array}$ & $\begin{array}{l}\text { Bachelor in Business } \\
\text { Administration }\end{array}$ & $\begin{array}{l}\text { Master in Business Administration } \\
\text { (MBA) }\end{array}$ & \\
\hline $\begin{array}{l}\text { Universidad Catolica Santiago De } \\
\text { Guayaquil (Guayaquil) }\end{array}$ & $\begin{array}{l}\text { Bachelor in International } \\
\text { Business }\end{array}$ & $\begin{array}{l}\text { Master in Business Administration } \\
\text { (MBA) }\end{array}$ & \\
\hline $\begin{array}{l}\text { Universidad Santa Maria } \\
\text { (Guayaquil) }\end{array}$ & $\begin{array}{l}\text { Bachelor in International } \\
\text { Business }\end{array}$ & $\begin{array}{l}\text { Master in Business Administration } \\
\text { (MBA) }\end{array}$ & \\
\hline $\begin{array}{l}\text { Universidad Casa Grande } \\
\text { (Guayaquil) }\end{array}$ & $\begin{array}{l}\text { Leadership Seminars for } \\
\text { managers }\end{array}$ & & \\
\hline $\begin{array}{l}\text { Universidad Del Pacifico (Quito, } \\
\text { Guayaquil Y Cuenca) }\end{array}$ & $\begin{array}{l}\text { Bachelor in International } \\
\text { Business, Leadership } \\
\text { Seminars for managers }\end{array}$ & & \\
\hline $\begin{array}{l}\text { Universidad Tecnologica } \\
\text { Empresarial De Guayaquil } \\
\text { (Guayaquil) }\end{array}$ & $\begin{array}{l}\text { Bachelor in Managerial } \\
\text { Business Administration }\end{array}$ & $\begin{array}{l}\text { Master in Business Administration } \\
\text { (MBA) }\end{array}$ & \\
\hline $\begin{array}{l}\text { Universidad Tecnologica America } \\
\text { (Quito, Y Guayaquil) }\end{array}$ & $\begin{array}{l}\text { Bachelor in Business } \\
\text { Administration }\end{array}$ & $\begin{array}{l}\text { Master in Business Administration } \\
\text { (MBA) }\end{array}$ & \\
\hline $\begin{array}{l}\text { Universidad Andina Simon Bolivar } \\
\text { (Quito) }\end{array}$ & $\begin{array}{l}\text { Bachelor in Business } \\
\text { Administration }\end{array}$ & $\begin{array}{l}\text { Master in Business Administration } \\
\text { (MBA) }\end{array}$ & $\begin{array}{l}\text { Business } \\
\text { Administration } \\
\text { PHD }\end{array}$ \\
\hline $\begin{array}{l}\text { Universidad De Guayaquil } \\
\text { (Guayaquil) }\end{array}$ & $\begin{array}{l}\text { Bachelor in Business } \\
\text { Administration }\end{array}$ & & \\
\hline $\begin{array}{l}\text { Pontificia Universidad Catolica Del } \\
\text { Ecuador (Quito, Ambato, } \\
\text { Esmeraldas, Ibarra) }\end{array}$ & $\begin{array}{l}\text { Bachelor in Business } \\
\text { Administration }\end{array}$ & $\begin{array}{l}\text { MASTER IN BUSINESS } \\
\text { ADMINISTRATION } \\
\text { (INTERNATIONAL BUSINESS) }\end{array}$ & \\
\hline $\begin{array}{l}\text { Universidad Politecnica Salesiana } \\
\text { (Quito, Cuenca, Guayaquil) }\end{array}$ & $\begin{array}{l}\text { Bachelor in Business } \\
\text { Administration }\end{array}$ & $\begin{array}{l}\text { Master in Business Administration } \\
\text { (MBA) }\end{array}$ & \\
\hline $\begin{array}{l}\text { Universidad Tecnica De Manabi } \\
\text { (Portoviejo) }\end{array}$ & $\begin{array}{l}\text { Bachelor in Business } \\
\text { Administration }\end{array}$ & & \\
\hline $\begin{array}{l}\text { Universidad Tecnologica } \\
\text { Equinoccial (Quito) }\end{array}$ & & $\begin{array}{l}\text { Master in Business Administration } \\
\text { (MBA) }\end{array}$ & \\
\hline $\begin{array}{l}\text { Universidad Internacional Del } \\
\text { Ecuador (Quito) }\end{array}$ & $\begin{array}{l}\text { Bachelor in Business } \\
\text { Administration }\end{array}$ & $\begin{array}{l}\text { Master in Business Administration } \\
\text { (MBA) }\end{array}$ & \\
\hline $\begin{array}{l}\text { Universidad De Las Americas } \\
\text { (Quito) }\end{array}$ & $\begin{array}{l}\text { Bachelor in International } \\
\text { Business }\end{array}$ & $\begin{array}{l}\text { Master in Business Administration } \\
\text { (MBA) }\end{array}$ & \\
\hline $\begin{array}{l}\text { Universidad Tecnica Estatal De } \\
\text { Quevedo (Quevedo) }\end{array}$ & $\begin{array}{l}\text { Bachelor Managerial } \\
\text { Business }\end{array}$ & & \\
\hline $\begin{array}{l}\text { Universidad Del Azuay (Cuenca, } \\
\text { Azuay) }\end{array}$ & $\begin{array}{l}\text { Bachelor in Business } \\
\text { Administration }\end{array}$ & $\begin{array}{l}\text { Master in Business Administration } \\
\text { (MBA) }\end{array}$ & \\
\hline $\begin{array}{l}\text { Universidad Metropolitana } \\
\text { (Guayaquil) }\end{array}$ & $\begin{array}{l}\text { Bachelor in Business } \\
\text { Administration }\end{array}$ & & \\
\hline Universidad Israel (Quito) & $\begin{array}{l}\text { Master in Business } \\
\text { Administration (MBA) }\end{array}$ & $\begin{array}{l}\text { Master in Business Administration } \\
\text { (MBA) }\end{array}$ & \\
\hline
\end{tabular}

*Source: The author of this work

\section{CONCLUSIONS}

The writer strongly believes that Ecuadorian managers can change their business culture and receive commensurate management education conducive to the effective and efficient operation, and subsequently, to the organizational development of their private enterprises (Theodore, 2004). A handful of large business organizations 
in the country whose managers were educated in North America and Europe in commensurate management curricula made significant contributions to the economic development of Ecuador during their seventy or more years of operation (Uggen, 2008). Managers of smaller organizations in the country can follow the successful steps of the handful of those large organizations and attain equal and/or better success as well. This can be done through the change of Ecuador's managerial culture, more government assistance and better cooperation with national and international universities that operate in the country. The latter involves increased and more vigorous management curricula and a synergistic rapport between such institutions and business organizations.

\section{AUTHOR INFORMATION}

John Theodore is the holder of a Ph.D. degree in Administration and Latin American Studies from the University of Kansas; a Ph.D. in Management from the Aristotelian University in Greece, European Union; and a D.B.A. in International Business from the University of South Africa. He has been teaching and consulting for four decades domestically and internationally. He is a visiting professor in various Latin American universities, including Ecuador.

\section{REFERENCES}

1. Acosta, A. (2006). Breve historia económica del Ecuador. Quito, Ecuador: Corporación editorial nacional.

2. Anderson, J. (1996). The New Battle of Puebla. Business México, (7) 2, 36-39

3. Arosemena-Arosemena, Guillermo (2007). Las empresas apuntan a fusiones. Expreso de Guayaquil. Abril 30, 14-15.

4. Arosemena-Arosemena, G. (2008). Hacia la superación gerencial, Industrias, Septiembre, 13(20).

5. Correa, S. (2008). Benchmarking: en busca de las mejores prácticas. Industrias, Noviembre 13 (11) ,36.

6. Crespo Merchan, M. (2008) Formamos gerentes estrategas o Profesionales administrativos? El Emprendedor. Editorial Santiago, Solano Gallegos. Diciembre 2008. 16-24

7. Haar, J. \& Price, J. (2008). Can Latin America complete? New York: Palgrave McMillan.

8. Hurtado, O. (2007). El poder político en Ecuador. (17 ${ }^{\mathrm{a}}$ ed.). Quito, Ecuador: Editorial Planeta del Ecuador.

9. Kwok, C. (1997). A global survey of international business. Journal of International Business (9) 3, 132135.

10. Luna Osorio, L. (2007). Proyección del Ecuador al mundo: 2007-2010. Quito, Ecuador: Pudeleco Editores.

11. Lucio-Paredes, P. (2008). En busca de la constitución perdida. Quito, Ecuador: TRAMA Ediciones.

12. Ospina Peralta, P. (2007). Nuestro Ecuador. Manual de realidad nacional. Quito, Ecuador: Universidad Andina Simón Bolívar.

13. Rigail, A (2006). La educación, la tecnología y la productividad laboral y Empresarial. Arco Consutores.2, $1-4$.

14. Rigail, Al. (2007). El rol de los gerentes generales para la Transformación de las pymes. Arco Consultores.3, 36.

15. Rigail, A (2008). La mentalidad de la abundancia. Arco Consultores.5, 4-8

16. Schein, E., H. (1985). Organizational culture and leadership. San Francisco: Jossey- Bass

17. Schalb, M, Grosse, R, \& Romero Simpson, E. (1998). Developing entrepreneurs in developing countries: The PEG program in Peru. Journal of Management Development 4 31-40.

18. Schein, E., H. (1988). Process consultation, Vol. 1: Its role in organization development. (2nd ed.) Reading, Mass: Addison-Wesley Publishing Company.

19. Theodore, J. (1971), A comparison of the development of management in the United States and Greece and the future of Greek Management (published in the Greek language). Athens, Greece. Ioannides Brothers Publishing House.

20. Theodore, J (1999). The impact of religious, social, and economic forces upon the development of management education in Latin America. Journal of Third World Studies. 16, (2), 133-139.

21. Theodore, J. (2002). Organization Development: Target Areas and Goals for Planned Change Interventions. The New Zealand Institute of Management, March-April

22. Theodore, J. (2003). Holistic management. EAN. 47, Enero-Abril 122-136.

23. Theodore, J. (2004). Desarrollo de organizaciones: una apuesta a la eficiencia. Ekos, Junio, $125-130$. 
24. Theodore, J. (March, 2009). Organizational size: A key element in the development of private enterprises in the less developed countries. The case of Ecuador. (http://cluteinstitute.org/IBERJMain.htm).

Proceedings of International Business \& Economics Research Conference CIBER Research Institute, San Antonio, Texas

25. Tiffin, Scott (Eds). (2004). Entrepreneurship in Latin America. Westport, CT: Praeger.

26. Uggen, $\mathrm{J}$ (2008). The emergence of multinational Enterprise in Ecuador: The case of the Ecuadorian corporation. Business and Economic History online 6, 3-8

27. Vásquez, L \& Santos, N. (2008). Ecuador: Su realidad. Quito, Ecuador. Fundación de investigación y promoción social "José Peralta"

\section{NOTES}

